\title{
Physicians' Dilemma of False-Positive RT-PCR for COVID-19: a Case Report
}

\author{
Sayak Roy ${ }^{1}$
}

Accepted: 18 November 2020 / Published online: 2 January 2021

(C) Springer Nature Switzerland AG 2021

\begin{abstract}
Coronavirus disease 2019 (COVID-19) has played havoc on this world's health and economics since its outbreak in December 2019. Reverse transcription-polymerase chain reaction (RT-PCR) has been the gold standard to diagnose severe acute respiratory syndrome coronavirus 2 (SARS-CoV-2). Still, few false-positive reports are emerging up that add to the physicians' dilemma and maintenance of health statistics.
\end{abstract}

Keywords Coronavirus disease 2019 - Reverse transcription-polymerase chain reaction · False-positive RT-PCR

\section{Introduction}

Coronaviruses (CoVs) are enveloped viruses, which have a positive single-stranded RNA genome and are pathogenic towards human beings [1]. Although the gold standard for detecting SARS-COV-2 infection is a quantitative RT-PCR assay [2], it has started to face rare cases of false-positive reports. Here, we discuss such a confusing case of probable falsepositive RT-PCR for SARS-COV-2.

\section{Case Presentation}

A 27-year-old male working at Andhra Pradesh presented to his doctor-on-call within his working area with a week history of large joint pains, 2-day history of fever with dry cough, and body pain. His pains seemed to have worsened since his fever started, and it was quite intense, although clinical examination did not reveal any inflamed joints or any chest findings. From his history, it became evident that he had been in contact with one of his colleagues 7 days back who recently tested COVID-19 RT-PCR positive. His RT-PCR for SARS-COV2 came positive on September 20, 2020, and he maintained the

This article is part of the Topical Collection on Covid-19

Sayak Roy

sayak.roy.123@gmail.com

1 Department of Internal Medicine, Medica Superspeciality Hospital, Kolkata, India home isolation protocols as laid down by the government. No repeat COVID-19 test was done by his employer, since he was labeled as a mild COVID-19 patient and, as per Indian government directive, a repeat test for COVID-19 is not indicated in mild infections. His joint pains persisted for two more months, and no other viral tests were done at that time of initial presentation. His computerized tomography (CT) scan of thorax, initial IgG SARS-COV-2 (October 11, 2020), repeat IgG SARS-COV-2 (November 9, 2020), and total IgG titer (November 9, 2020) showed normal CT findings, initial and repeat IgG SARS-COV-2 (both done 1 month apart) index value of 0.03 (non-reactive), and total $\operatorname{IgG} 14.8 \mathrm{~g} / \mathrm{L}$ respectively (Fig. 1).

The timeline of presentation and tests done is depicted in Fig. 2 below.

\section{Discussion and Conclusion}

The first thing that we have to remember is that no test is $100 \%$ perfect [3]. The real-time RT-PCR results using primers in various genes can easily get affected by the viral RNA sequence variations [4]. As per guidelines laid down by CDC (Centers for Disease Control and Prevention), the negative template control (NTC) sample should be negative, showing no fluorescence growth curves that cross the threshold line [5]. Sample contamination can lead to false-positive results with one or more of the primer and probe NTC reactions [5]. Confirmatory reporting guidelines should be maintained to avoid risks to patients emerging out of a false positive report. 
1. COVID-19 RT-PCR test $\left(20^{\text {th }}\right.$ September 2020)

\section{TEST RESULT (To be filled by Covid-19 testing lab facility)}

\begin{tabular}{|l|l|l|l|l|}
\hline $\begin{array}{l}\text { Date of sample } \\
\text { receipt(dd/mm/yy) }\end{array}$ & $\begin{array}{l}\text { Sample } \\
\text { accepted/ } \\
\text { Rejected }\end{array}$ & $\begin{array}{l}\text { Date of } \\
\text { Testing } \\
\text { (dd/mm/yy) }\end{array}$ & $\begin{array}{l}\text { Test result } \\
\text { (Positive I } \\
\text { Negative) }\end{array}$ & $\begin{array}{l}\text { Repeat Sample } \\
\text { required (Yes I } \\
\text { No) }\end{array}$ \\
\hline $\begin{array}{l}15-09-2020 \\
10: 22: 59 \text { AM }\end{array}$ & ACCEPTED & $\begin{array}{l}20-09-2020 \\
10: 55: 00 ~ A M\end{array}$ & POSITIVE & \\
\hline
\end{tabular}

\section{HRCT Thorax findings (6th October 2020)}

\section{Screening HRCT of Chest performed for SARS CoV-2 infection.}

Heart, pericardium and mediastinal vessels are normal.

There is no mediastinal, cervical or axillary adenopathy.

Esophagus is normal Tracheobronchial airway is patent with no intrabronchial occlusive or extrabronchial
compressive lesions.

Lung parenchyma is normal,

No pleural abnormality is seen.

Visualized abdominal organs are normal.

Impression: * Normal study of mediastinum and lungs.

\section{Initial IgG SARS-COV-2 result ( $11^{\text {th }}$ October 2020)}

\begin{tabular}{|c|c|c|c|}
\hline TEST NAME & TECHNOLOGY & VALUE & UNITS \\
\hline $\begin{array}{l}\text { COVID ANTIBODY IGG - C.M.I.A } \\
\text { Reference Range : }\end{array}$ & C.M.I.A & 0.03 & Index \\
\hline $\begin{array}{l}\text { Negative: }<1.40 \\
\text { Positive : }>=1.40\end{array}$ & & & \\
\hline $\begin{array}{l}\text { Kit used: SARS-COV-2 IgG, Manufactured } \\
\text { Uses recombinant protein representing the } \\
\text { Method : FULLY AUTOMATED CHEMILUMINES } \\
\text { Specification : Specificity : } 99.63 \% \text { \& Sensitivit }\end{array}$ & $\begin{array}{l}\text { diagnostics division } \\
\text { sid ( } n \text { ) antigen. } \\
\text { PARTICLE IMMUNOAS }\end{array}$ & & \\
\hline $\begin{array}{l}\text { COVID ANTIBODIES-TOTAL (CLIA) } \\
\text { Reference Range : }\end{array}$ & E.C.L.I.A & 0.08 & $\mathrm{COI}$ \\
\hline
\end{tabular}

\section{Repeat IgG SARS-COV-2 and, T otal IgG assay ( $9^{\text {th }}$ November 2020 )} IOTAL IGG, SERUM

TOTAL IGG

METHOD : NEPHELOMETRY

* SARS-COV-2 IGG ANTIBODY, SERUM

SARS-COV-2 IGG ANTIBODY

Fig. 1 HRCT thorax, initial and repeat IgG SARS-COV-2, and total IgG level 

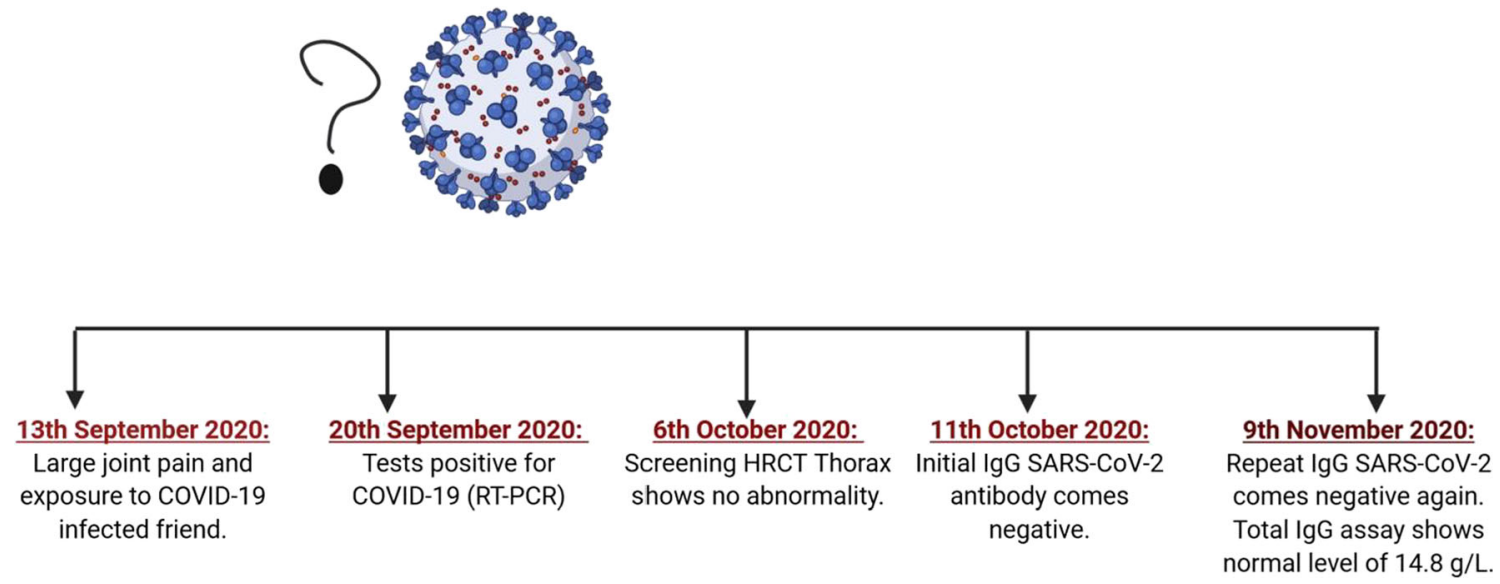

Fig. 2 Timeline of events. Created with BioRender.com

The FDA recommendations of using 100 contiguous bases for nucleic acid-based molecular diagnostics for viral disease infections are often not met by the probes used in CDC rRTPCR test kits for the SARS-CoV-2 assay, which are mostly about 25 bases long [6]. Traditionally, a PCR is supposed to be followed by a second separation technique that should be used for confirmation, which is not done in rRT-PCR used in screening or rapid diagnostic purposes [7]. Amplification errors are also possible if short probes are used in systems going beyond the cycle threshold $(\mathrm{Ct})$ of 40 used in general for amplification [7]. Detection of another non-SARS-CoV-2 virus/microorganism has also been postulated as one of the probable hypotheses of false-positive reports along with the interference of pure technical artifacts and chances of crosscontamination [8]. Sample mix-ups, data error, and software problems can also lead to false-positive results [9]. These studies have cited cross-contamination and carryover contamination to be the most probable reason for these false-positive results [9].

The patient who gets falsely stamped as COVID-19 positive faces tremendous mental agony, social stigma, and a very high risk of actually getting the infection if he or she is segregated or isolated in COVID-19 wards for observation. This might be due to the long contagious period of SARS-CoV-2infected patients, who might be present in those wards, which was found to be 20 days in one large scale study from China of 301 patients [10]. This study also showed a false positive RTPCR test in $30 \%$ (21 patients) of the study population who tested positive on third time testing, although their two previous reports came negative.

There has been a case report suggesting the potential role of CT chest in diagnosing a COVID-19 suspected patient whose RT-PCR came negative for the first four times, and CT chest showed the typical findings of patchy ground-glass opacity on admission, progressing rapidly to segmental mixed consolidation and ground-glass opacity 3 days post-admission [11]. This case and similar others [12] highlight the use of CT thorax as an aid to isolate suspected cases of COVID-19 infections.

The above instances shed light on few vital points for our health care setup: (a) organizing wards where suspected cases can be isolated till reports are available to curtail down the spread, (b) a repeat test of RT-PCR at $24 \mathrm{~h}$ and probably $48 \mathrm{~h}$ to minimize both false negative and false positive reports, and (c) making a CT thorax mandatory to aid in diagnosis and also prognosis by looking into the CT severity score [13].

Taking into consideration all the above discussions, we are left with few new unsolved questions for our false-positive case other than the normal probability of sampling error:

1. Was there any simultaneous RNA viral infection like Chikungunya at that time that could have cross-reacted, considering the typical prolonged joint pains he faced and the endemic zone of Andhra Pradesh state (where he worked) for Chikungunya fever [14]?

2. Is there any subset of patients who, even after having normal titers of total IgG, cannot mount up proper antibody response?

A case report from Singapore showed false-positive dengue rapid antigen tests due to underlying COVID-19 infection [15]. Hence, false-positive reports due to interaction between two RNA viruses are known. False-positive results have also been reported from pre-surgical cases, from 0.3 to $3 \%[8,16]$.

Our case report is another example of rare false-positive RT-PCR test for SARS-COV-2 reported from India. The significance of these false-positive reports is far-reaching, with effects on the mental health of the patient and loss of work power for the growing society in the face of this pandemic. Proper confirmatory tests must be performed before delivering positive reports in the SARS-COV-2 infection.

Author's Contribution The whole manuscript was written and revised by the single corresponding author. 
Data Availability Available on request with the author.

\section{Compliance with Ethical Standards}

Conflict of Interest The author declares that he has no conflicts of interest.

Consent Prior written informed consent was taken from the patient.

Ethical Clearance Not required as per law of the land, since it is a case report.

Consent for Publication Prior written informed consent to publish in medical journal for knowledge sharing purpose was taken.

\section{References}

1. Naqvi AAT, Fatima K, Mohammad T, et al. Insights into SARSCoV-2 genome, structure, evolution, pathogenesis and therapies: structural genomics approach. Biochim Biophys Acta Mol basis Dis. 2020;1866(10):165878 Available at: https://www.ncbi.nlm. nih.gov/pmc/articles/PMC7293463/.

2. Oliveira BA, Oliveira LC, Sabino EC, Okay TS. SARS-CoV-2 and the COVID-19 disease: a mini review on diagnostic methods. Rev Inst Med Trop Sao Paulo. 2020;62:e44. https://doi.org/10.1590/ S1678-9946202062044.

3. Watson J, Whiting PF, Brush JE. Interpreting a covid-19 test result. BMJ. 2020;369. Available at: https://www.bmj.com/content/369/ bmj.m1808.

4. Phan T. Genetic diversity and evolution of SARS-CoV-2. Infect Genet Evol. 2020;81:104260. https://doi.org/10.1016/j.meegid. 2020.104260 .

5. https://www.cdc.gov/coronavirus/2019-ncov/lab/index.html? CDC_AA_refVal=https $\% 3 \mathrm{~A} \% 2 \mathrm{~F} \% 2 \mathrm{Fwww} . \mathrm{cdc} . \mathrm{gov} \%$ 2Fcoronavirus \%2F 2019-ncov\%2Flab\%2Frt-pcr-detectioninstructions.html. Accessed 9 Nov 2020.

6. Lee SH. Testing for SARS-CoV-2 in cellular components by routine nested RT-PCR followed by DNA sequencing. Int J Geriatr Rehab. 2020;2:69-96.

7. www.aacc.org. (n.d.). False positive results in real-time reverse transcription-polymerase chain reaction (rRT-PCR) for SARS-
CoV-2? | AACC.org. [online] Available at: https://www.aacc.org/ science-and-research/scientific-shorts/2020/false-positive-resultsin-real-time-reverse-transcription-polymeras. Accessed 9 Nov. 2020.

8. Katz AP, Civantos FJ, Sargi Z, Leibowitz JM, Nicolli EA, Weed D, et al. False-positive reverse transcriptase polymerase chain reaction screening for SARS-CoV-2 in the setting of urgent head and neck surgery and otolaryngologic emergencies during the pandemic: clinical implications. Head Neck. 2020;42:1621-8. https://doi.org/ 10.1002/hed.26317.

9. Cohen AN, Kessel B. False positives in reverse transcription PCR testing for SARS-CoV-2. 2020. https://doi.org/10.1101/2020.04. 26.20080911.

10. Xiao AT, Tong YX, Gao C, Zhu L, et al. Dynamic profile of RTPCR findings from 301 COVID-19 patients in Wuhan, China: a descriptive study. J Clin Virol. 2020;127:104346. https://doi.org/ 10.1016/j.jcv.2020.104346.

11. Feng H, Liu Y, Lv M, Zhong J. A case report of COVID-19 with false negative RT-PCR test: necessity of chest CT. Jpn J Radiol. 2020;38(5):409-10. https://doi.org/10.1007/s11604-020-00967-9.

12. Xie X, Zhong Z, Zhao W, et al. Chest CT for typical coronavirus disease 2019 (COVID-19) pneumonia: relationship to negative RTPCR testing. Radiology. 2020;296(2):E41-5. https://doi.org/10. 1148/radiol.2020200343.

13. Yang R, Li X, Liu H, et al. Chest CT Severity Score: an imaging tool for assessing severe COVID-19. Radiol Cardiothorac Imaging. 2(2):e200047.

14. Mohan A, Kiran DH, Manohar IC, Kumar DP. Epidemiology, clinical manifestations, and diagnosis of Chikungunya fever: lessons learned from the re-emerging epidemic. Indian J Dermatol. 2010;55(1):54-63. https://doi.org/10.4103/0019-5154.60355.

15. Correction to Lancet Infect Dis 2020; published online Aug 3. Lancet Infect Dis. 2020;20(10), e250. https://doi.org/10.1016/ S1473-3099(20)30589-2.

16. Albendin-Iglesias H, Mira-Bleda E, Roura-Piloto AE, et al. Usefulness of the epidemiological survey and RTePCR test in pre-surgical patients for assessing the risk of COVID-19. J Hosp Infect. 2020;105(4):773-5. https://doi.org/10.1016/j.jhin.2020.06. 009.

Publisher's Note Springer Nature remains neutral with regard to jurisdictional claims in published maps and institutional affiliations. 